\title{
A STUDY OF ABDOMINAL GOSSYPIBOMA
}

\author{
Rajiv Jain ${ }^{1}$, Mohan Gadodia ${ }^{2}$
}

${ }_{1}^{1}$ Associate Professor, Department of General Surgery, Sri Aurobindo Medical College \& Post Graduate Institute. ${ }^{2}$ Resident, Department of General Surgery, Sri Aurobindo Medical College \& Post Graduate Institute.

\section{ABSTRACT}

\section{BACKGROUND}

Gossypiboma or textiloma is a term specifically coined to describe a retained surgical sponge in the body after a surgical procedure. Any foreign body accidentally left in the abdomen often requires reoperation for its removal which increases the morbidity of the patient, cost of treatment and medico legal problems. The aim of this research is to study the incidence, presenting features, management and outcome of Abdominal Gossypiboma. Design: Retrospective study. Setting \& Duration: Department of Surgery, Sri Aurobindo Medical College \& PG Institute, Indore, from 2005 to 2015. Patients: Patients presenting with a history of previous surgery, signs of an abdominal lump or acute abdomen, which turned out to be a Gossypiboma either in radiological investigations or during surgery were included in the study.

\section{METHODOLOGY}

The data of patients who underwent Laparotomy in last 10 years was collected from Medical Records Department and the cases of Abdominal Gossypiboma were selected. All the patients were clinically evaluated and radiological examinations of patients were done to confirm diagnosis. Every patient was optimized and subjected to Laparotomy.

\section{RESULTS}

A total of 6889 laparotomy operations were performed during this period, which translate incidence of Abdominal Gossypiboma to be one in 574 operations. A total number of 12 patients of Gossypibomas were studied, which presented with signs and symptoms of an abdominal mass with or without signs of acute abdomen. X-ray findings were foreign body with whorl appearance and gas bubbles. Ultrasound revealed hypo-echoic densities with encapsulation. Exploratory laparotomy was done in all the 12 cases.

\section{CONCLUSION}

Gossypiboma is rare but serious complication of any surgical procedure and hence every possible measure should be taken to prevent its occurrence. We recommend the adoption of a very systematic swab and instrument counting policy to prevent this complication.

\section{KEYWORDS}

Retained Sponge, Gossypiboma, Medico-legal.

HOW TO CITE THIS ARTICLE: Jain R, Gadodia M. A study of abdominal gossypiboma. J. Evolution Med. Dent. Sci. 2016;5(44): 2725-2730, DOI: $10.14260 /$ jemds/2016/637

\section{INTRODUCTION}

Gossypiboma, is a term derived from the combination of Latin words "Gossypium" meaning cotton and Swahili word "Boma," which means place of concealment. It is a mass within the body consisting of a surgical sponge (Cotton matrix) surrounded by an inflammatory reaction. Surgical sponge left involuntarily inside a body cavity is a serious, but avoidable complication.

In the abdomen the surgical sponge or any foreign body can be surrounded by omentum and intestines, which attempt to encapsulate it in order to localize any foreign body reaction, but in the process various grievous complications can take place.

The pressure and irritation on the intestines can hamper the blood supply and lead to gangrene of the bowel loops with

Financial or Other, Competing Interest: None.

Submission 24-02-2016, Peer Review 22-03-2016,

Acceptance 28-03-2016, Published 01-06-2016.

Corresponding Author:

Dr. Rajiv Jain,

27, Anand Bagichi,

Agrawal Nagar,

Indore-452001,

Madhya Pradesh.

E-mail: drrajivjain16@yahoo.com

DOI: $10.14260 /$ jemds $/ 2016 / 637$ the sponge eroding through its walls into the lumen. This can lead to intestinal obstruction, fistula formation or gangrenous bowel.

The reported incidence of gossypiboma is one in 100-5000 operations. Occurrence of this complication is very rare in western countries due to their strict adherence to operation theatre policies.

\section{METHODOLOGY}

We searched the medical records of all the patients who had undergone Laparotomy surgery during the study period of 10 years, i.e. from 2005 to 2015 . We found a total of 12 confirmed cases of Abdominal Gossypiboma [Retained Surgical Sponge] after going through the medical records. All of these patients were treated in Department of Surgery, Sri Aurobindo Medical College and PG Institute during this period.

This medical college is a tertiary care centre of central India, catering to a large number of population from Madhya Pradesh state and the surrounding states. Relevant data about these 12 patients was retrieved from the Medical Records Department. The collected data was analysed and recorded in the parameters of age, sex, details of previous surgery, clinical presentation, investigations, intraoperative findings and postoperative complications. All the patients were 
radiologically evaluated by plain X-ray of abdomen, ultrasound and CT scan according to the individual case requirement. All patients were diagnosed as cases Abdominal Gossypiboma, presenting either as abdominal lump or acute abdomen and all had undergone exploratory laparotomy.

Pre-operative diagnosis of Gossypiboma was possible in 9 cases with the help of clinical and radiological methods; whereas in the remaining 3 cases, diagnosis of gossypiboma could only be made during laparotomy. Exploratory laparotomy was performed in all 12 cases to retrieve the retained surgical sponge and the abdomen was closed after successful removal of the retained sponge.

\section{RESULTS}

During the study period of 10 years [From 2005 to 2015], total number of Laparotomies done in our hospital were 6889; and out of these 12 cases of abdominal gossypiboma were confirmed. Thus the incidence of Gossypiboma comes to be 1 in 574 operations in our study.

There were 4 males [33\%] and 8 females [67\%] and the age range was from 25 to 62 years with mean age around 40 years.

The clinical presentation was quite varied. Four patients presented with signs of acute intestinal obstruction like abdominal pain, bilious vomiting, absolute constipation and abdominal distension. Three patients presented with signs of perforation peritonitis like abdominal distension, absent bowel sounds, rigidity and tenderness. Five patients presented with slowly growing, painless abdominal lump as the only complaint.

History of previous abdominal surgery was present in all the patients. Two patients had undergone surgery in our institute and the remaining ten were operated at various periphery hospitals. The mean time interval between previous surgery and diagnosis of gossypiboma was 58 months with range varying from 8 months to 8 years.

After going through the details of previous abdominal surgery, we found that in three cases each sponges were retained after Laparotomy and Splenectomy. There was history of previous cholecystectomy in 2 cases, whereas remaining four operations were Ureterolithotomy, Appendicectomy, Caesarean section and Abdominal Hysterectomy [One case each]; 5 operations had been done in emergency settings and remaining 7 operations had been done as routine planned procedures. But of these 7 elective operations, in 5 cases there have been some unexpected haemorrhages which led to the intraoperative delay.

\begin{tabular}{|c|c|c|c|c|c|c|}
\hline $\begin{array}{l}\text { Case } \\
\text { No. }\end{array}$ & $\begin{array}{l}\text { Age/ } \\
\text { Sex }\end{array}$ & $\begin{array}{c}\text { Name of } \\
\text { Previous } \\
\text { Operation }\end{array}$ & $\begin{array}{c}\text { Indication of } \\
\text { Previous Operation }\end{array}$ & $\begin{array}{c}\text { Previous } \\
\text { Operation } \\
\text { [Emergency/ } \\
\text { Routine] }\end{array}$ & $\begin{array}{c}\text { Duration } \\
\text { between } \\
\text { Previous } \\
\text { Operation and } \\
\text { Onset of Current } \\
\text { Symptoms } \\
\text { (In Months) } \\
\end{array}$ & $\begin{array}{c}\text { Clinical } \\
\text { Presentation }\end{array}$ \\
\hline 1 & $26 \mathrm{y} / \mathrm{M}$ & Laparotomy & Perforation Peritonitis & Emergency & 96 & $\begin{array}{c}\text { Perforation } \\
\text { Peritonitis } \\
\end{array}$ \\
\hline 2 & $30 \mathrm{y} / \mathrm{F}$ & Splenectomy & Tropical Splenomegaly & Routine & 8 & $\begin{array}{l}\text { Perforation } \\
\text { Peritonitis } \\
\end{array}$ \\
\hline 3 & $42 \mathrm{y} / \mathrm{F}$ & Cholecystectomy & $\begin{array}{l}\text { Symptomatic } \\
\text { Cholelithiasis }\end{array}$ & Routine & 28 & $\begin{array}{c}\text { Perforation } \\
\text { Peritonitis }\end{array}$ \\
\hline 4 & $46 \mathrm{y} / \mathrm{M}$ & Laparotomy & Perforation Peritonitis & Emergency & 60 & $\begin{array}{c}\text { Intestinal } \\
\text { Obstruction }\end{array}$ \\
\hline 5 & $55 \mathrm{y} / \mathrm{F}$ & Laparotomy & Intestinal Obstruction & Emergency & 72 & $\begin{array}{c}\text { Intestinal } \\
\text { Obstruction }\end{array}$ \\
\hline 6 & $25 \mathrm{y} / \mathrm{F}$ & Splenectomy & $\begin{array}{c}\text { Idiopathic } \\
\text { Thrombocytopenic } \\
\text { Purpura }\end{array}$ & Routine & 54 & $\begin{array}{l}\text { Intestinal } \\
\text { Obstruction }\end{array}$ \\
\hline 7 & $60 \mathrm{y} / \mathrm{F}$ & $\begin{array}{c}\text { Abdominal } \\
\text { Hysterectomy }\end{array}$ & Uterine Fibroid & Routine & 96 & $\begin{array}{c}\text { Intestinal } \\
\text { Obstruction }\end{array}$ \\
\hline 8 & $45 \mathrm{y} / \mathrm{F}$ & Cholecystectomy & Chronic Cholecystitis & Routine & 44 & $\begin{array}{l}\text { Abdominal } \\
\text { Lump }\end{array}$ \\
\hline 9 & $28 \mathrm{y} / \mathrm{M}$ & Appendicectomy & $\begin{array}{c}\text { Perforated } \\
\text { Appendicitis }\end{array}$ & Emergency & 84 & $\begin{array}{l}\text { Abdominal } \\
\text { Lump }\end{array}$ \\
\hline 10 & $62 \mathrm{y} / \mathrm{M}$ & Ureterolithotomy & Right Ureteric Calculus & Routine & 76 & $\begin{array}{l}\text { Abdominal } \\
\text { Lump }\end{array}$ \\
\hline 11 & $30 \mathrm{y} / \mathrm{F}$ & Splenectomy & $\begin{array}{l}\text { Hypersplenism with } \\
\text { Massive Splenomegaly }\end{array}$ & Routine & 12 & $\begin{array}{l}\text { Abdominal } \\
\text { Lump }\end{array}$ \\
\hline 12 & $31 \mathrm{y} / \mathrm{F}$ & Caesarean Section & Abruptio Placenta & Emergency & 66 & $\begin{array}{l}\text { Abdominal } \\
\text { Lump }\end{array}$ \\
\hline
\end{tabular}

Patients with asymptomatic lumps were evaluated by radiological methods and planned for elective exploratory laparotomy. And the patients which presented with acute abdomen [perforation peritonitis and intestinal obstruction] were initially resuscitated, evaluated and then subjected to emergency exploratory laparotomy.

The investigations used for evaluation were erect abdominal radiograph, ultrasonography abdomen and CT scan 
of abdomen apart from routine haematological and biochemical tests.

Preoperative diagnosis of retained surgical sponge was made in 9 cases, while in 3 cases the confirmed diagnosis was possible during surgery only.

During surgery, in the cases which were diagnosed as intestinal obstruction [4 cases], the retained sponge was found between intestinal loops covered by fibrous tissues and causing dense adhesions between the bowel loops. Sharp dissection was done to separate the entangled bowel loops and the sponge was removed without damage to the adhered bowel loops.

Out of the 3 cases which were diagnosed as perforation peritonitis, in case no. 1 the retained sponge was found eroding the anterior wall of stomach. The sponge was removed and the rent in stomach was repaired in 2 layers. In case no. 2, the retained sponge folded in 2 layers was lying embedded in the transverse mesocolon and causing a large perforation on the mesenteric border of transverse colon. The sponge and involved part of mesocolon was removed and primary repair of colonic perforation was done in two layers. This patient developed a leak from the repair site in the postoperative period and subsequently burst abdomen. Relook laparotomy was done and the transverse loop colostomy was fashioned. While in Case No. 3, the sponge was forming an inseparable cocoon with loops of small bowel. Resection of involved segment of about one foot of Jejunum and end-to-end jejunojejunal anastomosis was done.

Out of the 5 patients who presented with asymptomatic lumps during surgery, the sponge was found at various places like adhered to anterior abdominal wall, uterus and adnexa, splenic fossa, etc. In Case No. 8, the sponge was found adhered to anterior abdominal wall and small bowel loops and left adnexa. While the other locations were right paracolic gutter [Case No. 9], pelvis [Case No. 10], splenic fossa [Case No. 11] and uterus and adnexa [Case No. 12]. In all cases, the sponge was removed by meticulous dissection without damage to adhered structures.

The patients who underwent planned laparotomies for asymptomatic lumps had uneventful recovery with no morbidity. Out of 4 patients of intestinal obstruction, 2 patients had prolonged ileus and 3 patients had wound related complications like seroma, pus discharge, etc. which were managed by conservative methods.

Out of the 3 patients of perforation peritonitis, all had wound related complications and 1 had burst abdomen [Case No. 2]. One patient [Case No. 2] developed a leak from repaired transverse colon perforation, which was detected on $5^{\text {th }}$ POD. Relook laparotomy was done and loop transverse colostomy was fashioned. There was no mortality in our study.

\begin{tabular}{|c|c|c|c|c|}
\hline $\begin{array}{l}\text { Case } \\
\text { No. }\end{array}$ & $\begin{array}{c}\text { Case } \\
\text { Diagnosis }\end{array}$ & $\begin{array}{l}\text { Operation } \\
\text { Done }\end{array}$ & $\begin{array}{l}\text { Intra-Operative } \\
\text { Findings }\end{array}$ & $\begin{array}{l}\text { Post-Operative } \\
\text { Complications }\end{array}$ \\
\hline 1. & $\begin{array}{l}\text { Perforation } \\
\text { Peritonitis }\end{array}$ & $\begin{array}{l}\text { Exploratory } \\
\text { Laparotomy }\end{array}$ & Sponge Causing Gastric Perforation & Wound Seroma \\
\hline 2. & $\begin{array}{l}\text { Perforation } \\
\text { Peritonitis }\end{array}$ & $\begin{array}{l}\text { Exploratory } \\
\text { Laparotomy }\end{array}$ & Sponge Eroding Transverse Colon & $\begin{array}{l}\text { Burst Abdomen and Re- } \\
\text { Exploration }\end{array}$ \\
\hline 3. & $\begin{array}{l}\text { Perforation } \\
\text { Peritonitis }\end{array}$ & $\begin{array}{l}\text { Exploratory } \\
\text { Laparotomy }\end{array}$ & $\begin{array}{l}\text { Sponge Forming Inseparable Cocoon with Small } \\
\text { Bowel Loops }\end{array}$ & Wound Pus Discharge \\
\hline 4. & $\begin{array}{l}\text { Intestinal } \\
\text { Obstruction }\end{array}$ & $\begin{array}{l}\text { Exploratory } \\
\text { Laparotomy }\end{array}$ & Sponge Adhered to Distal Ileum and Caecum & Prolonged Ileus \\
\hline 5. & $\begin{array}{c}\text { Intestinal } \\
\text { Obstruction }\end{array}$ & $\begin{array}{l}\text { Exploratory } \\
\text { Laparotomy }\end{array}$ & Sponge Adhered to Ileal Loops & Wound Seroma \\
\hline 6. & $\begin{array}{l}\text { Intestinal } \\
\text { Obstruction }\end{array}$ & $\begin{array}{l}\text { Exploratory } \\
\text { Laparotomy }\end{array}$ & Sponge Adhered to Jejunal Loops & Wound Pus Discharge \\
\hline 7. & $\begin{array}{l}\text { Intestinal } \\
\text { Obstruction }\end{array}$ & $\begin{array}{l}\text { Exploratory } \\
\text { Laparotomy }\end{array}$ & Sponge Adhered to Ileal Loops and Sigmoid Colon & $\begin{array}{l}\text { Prolonged Ileus and } \\
\text { Wound Seroma }\end{array}$ \\
\hline 8. & $\begin{array}{l}\text { Abdominal } \\
\text { Lump }\end{array}$ & $\begin{array}{l}\text { Exploratory } \\
\text { Laparotomy }\end{array}$ & $\begin{array}{l}\text { Sponge Densely Adherent to Anterior Abdominal } \\
\text { Wall, Small Bowel Loops \& Left Adnexa }\end{array}$ & None \\
\hline 9. & $\begin{array}{l}\text { Abdominal } \\
\text { Lump }\end{array}$ & $\begin{array}{l}\text { Exploratory } \\
\text { Laparotomy }\end{array}$ & $\begin{array}{c}\text { Sponge in Right Paracolic Gutter with Flimsy } \\
\text { Adhesions to Small Bowel Loops }\end{array}$ & None \\
\hline 10. & $\begin{array}{l}\text { Abdominal } \\
\text { Lump }\end{array}$ & $\begin{array}{l}\text { Exploratory } \\
\text { Laparotomy }\end{array}$ & $\begin{array}{l}\text { Sponge Lying in Pelvis and Adherent to } \\
\text { Surrounding Structures }\end{array}$ & None \\
\hline 11 & $\begin{array}{l}\text { Abdominal } \\
\text { Lump }\end{array}$ & $\begin{array}{l}\text { Exploratory } \\
\text { Laparotomy }\end{array}$ & Sponge in Splenic Fossa and Adherent to Parieties & None \\
\hline 12. & $\begin{array}{l}\text { Abdominal } \\
\text { Lump }\end{array}$ & $\begin{array}{l}\text { Exploratory } \\
\text { Laparotomy }\end{array}$ & Sponge Adhered to Uterus and Right Adnexa & None \\
\hline
\end{tabular}

\section{DISCUSSION}

Gossypiboma or retained sponge is an important topic of discussion, as it leads to significant embarrassment and can lead to humiliation and lawsuit as well. The reported incidence of gossypiboma varies in different studies and the actual number is difficult to ascertain, because of low reporting rate due to medico legal implications. ${ }^{1}$ In world literature, various authors like Noyle. ${ }^{2}$ Zbar. $^{3}$ and Risher. ${ }^{4}$ have reported incidence of Gossypiboma to be one in 100 to 5000 operations. In our study, incidence was found to be 1 in 574 operations.

In various studies, it has been found that females are in excess than males. In our study, 8 patients [66\%] were females. 
Gossypiboma is most commonly seen during emergency surgery, unexpected change in the surgical procedure, disorganization (e.g. poor communication), change in surgical team or scrub nurses, hurried sponge counts, long operations, unstable patient, inexperienced staff, inadequate staff numbers and obesity. ${ }^{5}$

In our study, five cases of gossypiboma were seen after emergency operations [42\%] and in the rest seven cases [58\%], sponges were retained after routine surgeries. But out of these 7 elective cases, in 5 cases there have been some intraoperative event that has led to increase in the operative time. In a study conducted by Bani-Hani et al, $63.6 \%$ patients had a previous emergency operation. ${ }^{6}$ In a similar study done by Gawande et al, they found that retained sponges are nine times more likely after an emergency operation and four times more common when an unexpected change in the surgical procedure is undertaken. ${ }^{7}$

A surgical sponge can be retained after any surgery but most commonly, laparotomy, hysterectomy, appendectomy and cholecystectomy are associated with this problem. ${ }^{4}$ In the current study, in three cases each sponges were retained after Laparotomy [25\%] and splenectomy [25\%]. The remaining operations involved were cholecystectomy, ureterolithotomy, appendicectomy, caesarean section and abdominal hysterectomy.

Apter et $\mathrm{al}^{8}$ and Botet Del Castillo et al ${ }^{9}$ reported that retained sponge is most frequent after gynaecological procedures followed by upper abdominal operations.

The clinical presentation of gossypiboma is variable and depends on the location of the sponge and the type of reaction. There are two types of foreign body reactions in pathology: an exudative inflammatory reaction leading to abscess formation or chronic internal or external fistula formation. Another is an aseptic fibrinous reaction resulting in adhesion, encapsulation and eventual formation of granuloma. The latter usually presents much later than exudates reaction sequelae. They usually remain asymptomatic or present with pseudotumour syndrome. Common symptoms and signs of gossypiboma are abdominal distension, ileus, tenesmus, pain, palpable mass, diarrhoea, abscess and fistula formation, nausea, vomiting, anorexia and weight loss resulting from obstruction or a malabsorption type syndrome caused by the multiple intestinal fistulas or intraluminal bacterial overgrowth. Intraabdominal gossypibomas can migrate into the ileum, stomach, colon or bladder without any apparent opening in the wall of these luminal organs. ${ }^{8}$

Although the most common site reported is the abdominal cavity, almost any cavity or surgical procedure may be involved. Other sites reported are the nose, tracheobronchial tree, breast, pancreas, pararenal space, vagina, femur and spine. In our study, we have only included the Abdominal Gossypibomas.

Retained sponges may cause serious consequences such as bowel perforation, obstruction or fistula formation, sepsis or even death. ${ }^{10}$ In our series, the retained sponge was implicated to cause perforation in either stomach or bowel [3 cases, i.e. $25 \%$ ], while in 4 patients [33\%] the retained sponge was found adhered to bowel loops causing intestinal obstruction. In the remaining cases [42\%], the retained sponge was found adhered to various visceral structures without causing any deleterious consequences.
Imaging is often diagnostic in such cases. Radiographs are the most commonly used method to detect retained sponges. ${ }^{11}$ If the sponge contains a radiopaque marker, the diagnosis can be made easily on conventional radiography. Radiographs can also suggest the diagnosis when a characteristic whorl-like pattern is present.

Ultrasound features are usually a well-delineated mass containing a wavy internal echo with a hypoechoic ring and strong posterior acoustic shadowing. ${ }^{12}$

CT is the technique of choice for detecting gossypibomas and possible complications. The spongiform pattern with gas bubbles is the most characteristic CT sign for gossypibomas. ${ }^{12}$

In our study, preoperative diagnosis could be made in nine cases [75\%] by different imaging modalities. Ultrasonography was done in all cases and was confirmatory in 5 cases. CECT scan of whole abdomen was done in 10 cases to evaluate the abdominal lump and possible complications and this was confirmatory in 7 cases. In rest of the 3 cases, gossypiboma could be diagnosed only during laparotomy.

Removal of a retained sponge usually requires a laparotomy, but in literature other methods are also described. Childers and Caplinger. ${ }^{13}$ have reported removal of a retained sponge through a laparoscope, whereas percutaneous retrieval of intra-peritoneal sponges has been accomplished successfully by interventional radiologists.

The time interval between initial operation and sponge retrieval surgery has been reported from 6 months to 7 years. ${ }^{14}$ In our study, in all the cases the retained sponge was retrieved by exploratory laparotomy and the time interval was 8 months to 8 years with mean of 58 months.

In our series, minor postoperative complications were seen in 6 patients. These were wound seroma [25\%], wound infection and pus discharge [17\%] and prolonged ileus [17\%]. One patient had serious postoperative complication. He developed leak from the repaired site of transverse colon leading to formation of faecal fistula and subsequently burst abdomen. Re-exploration and colostomy was done and the complication was managed successfully and the patient recovered well. There was no mortality in our study.

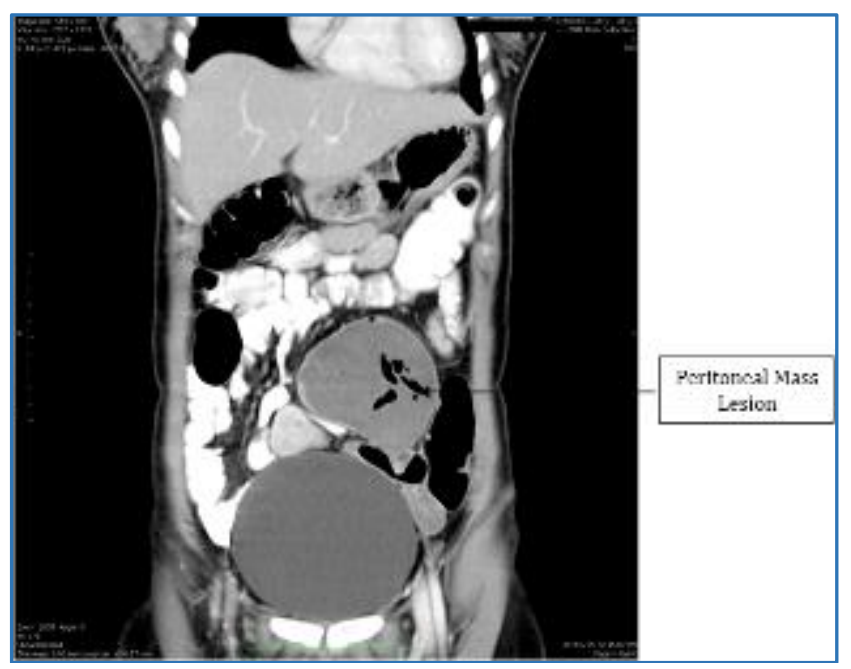

Fig. 1: Axial CT Scan - Post Contrast Image showing Well Defined Ovoid Thin Rim Enhancing Peritoneal Mass Lesion at the Level of Umbilicus with Displacement of Surrounding Bowel-Gossypiboma [Case 8] 


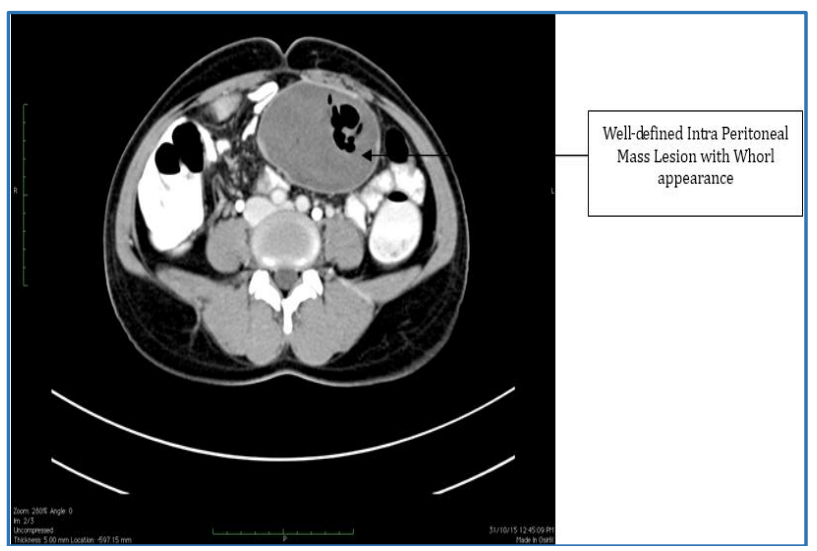

Fig. 2: CT Scan Coronal View of a Patient of Gossypiboma [Case 8]

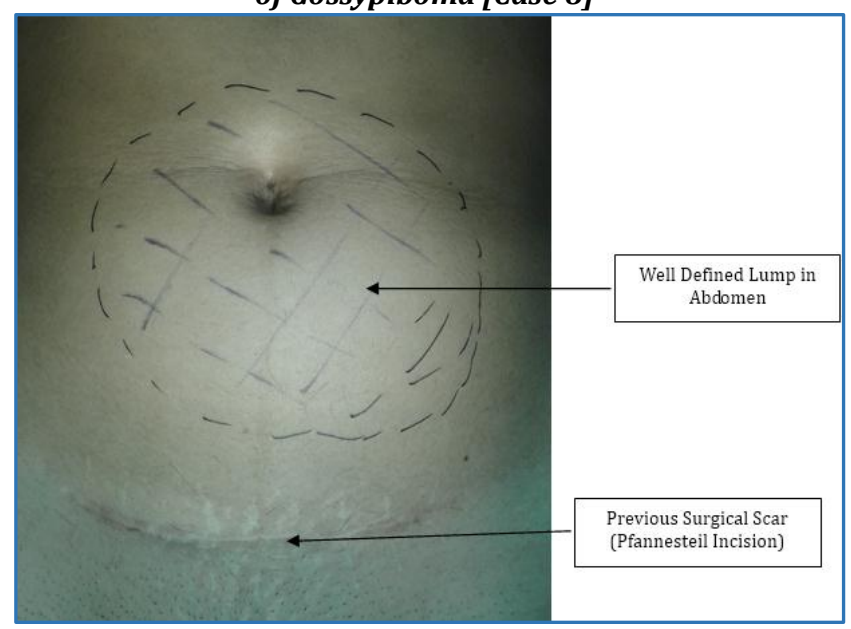

Fig. 3: Photograph of a Patient showing Abdominal Lump and Scar of Previous Surgery [Case 7]

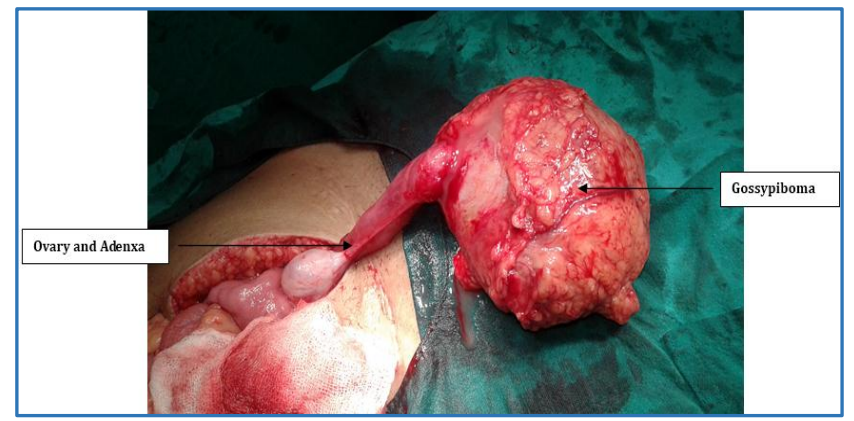

Fig. 4: Intraoperative Photograph showing Gossypiboma Adhered to Adnexa [Case 12]

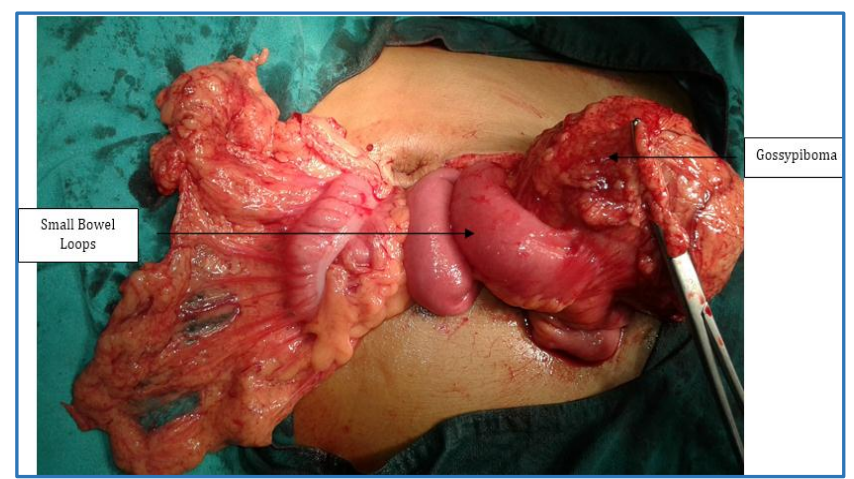

Fig. 5: Intraoperative Photograph showing Gossypiboma Adhered to Small Bowel Loops [Case 5]

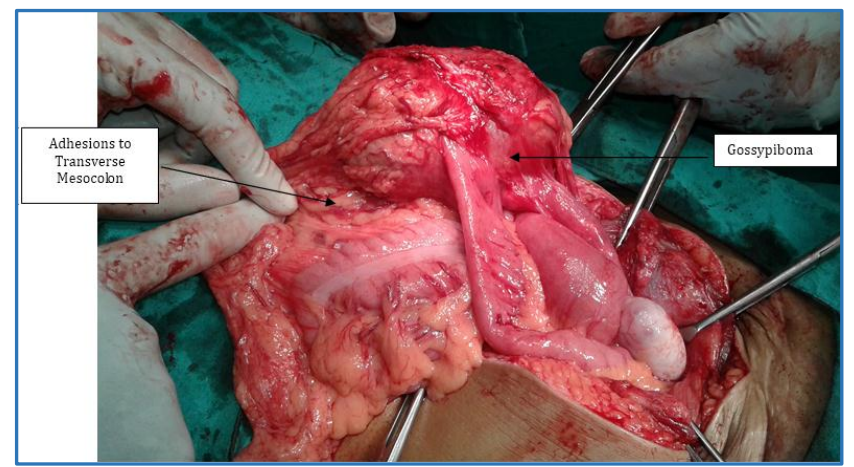

Fig. 6: Intraoperative Photograph showing Gossypiboma Adhered to Transverse Mesocolon and Adjacent Structures [Case 2]

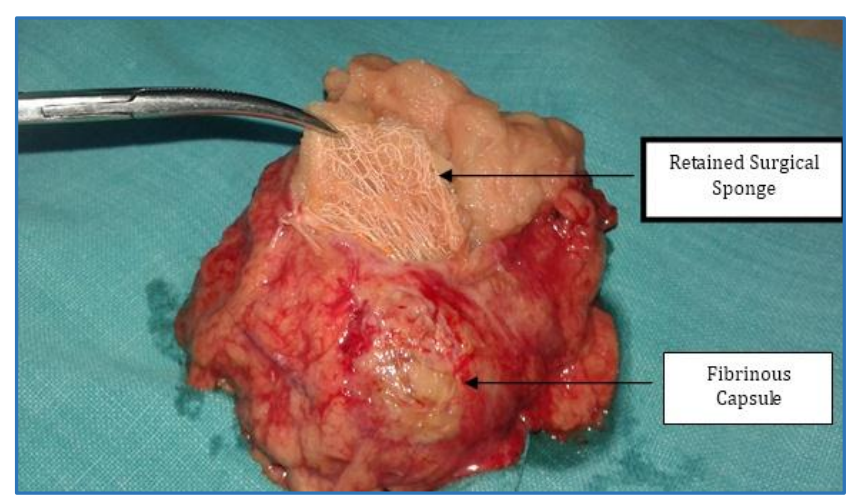

Fig. 7: Photograph of Specimen showing Retained Sponge Inside a Fibrinous Capsule [Case 10]

\section{CONCLUSION}

Gossypiboma is a rare, avoidable, but serious postoperative complication. It is usually asymptomatic and generally has nonspecific clinical findings. Hence, the diagnosis is often delayed. Abdominal Gossypiboma can cause wide variety of complications like perforation of viscera and adhesion to the adjacent structures. It can also be a cause for serious medicolegal problems. It is best to avoid gossypiboma. The surgeons should comply with the current recommendations on the prevention of retained foreign bodies including use of radiological markers and routine pre- and post-operative sponge count. Gossypiboma should be included in the differential diagnosis of soft-tissue masses or localized abdominal pains in patients with a history of prior operation.

\section{REFERENCES}

1. Uluçay $T$, Dizdar MG, Sunay Yavuz $M$, et al. The importance of medico-legal evaluation in a case with intraabdominal gossypiboma. Forensic Science International 2010;198(1-3):15-8.

2. Noyle H, Hines OJ, Fadden Mc DW. Gossypibomas of the abdomen. Arch Surg 1996;131(5):566-8.

3. Zbar AP, Agrawal A, Saeedi IT, et al. Gossypiboma revisited: a case report and review of literature. J R Coll Surg Edinb 1998;43(6):417-8.

4. Risher WH, Kinnon Mc WM. Foreign body in the gastro intestinal tract: intra luminal migration of a laparotomy sponge. South Med J 1991;84(8):1042-45.

5. Sun HS, Chen SL, Kuo CC, et al. Gossypiboma-retained surgical sponge. J Chin Med Assoc 2007;70(11):511-3. 
6. Bani-Hani KE, Gharaibeh KA, Yaghan RJ. Retained surgical sponges (gossypiboma). Asian J Surg 2005;28(2):109-15.

7. Gawande AA, Studdert DM, Orav EJ, et al. Risk factors for retained instruments and sponges after surgery. $\mathrm{N}$ Engl J Med 2003;348:229-35.

8. Apter S, Hertz M, Rubinstein ZJ, et al. Gossypiboma in the early postoperative period: a diagnostic problem. Clin Radiol 1990;42(2):128-9.

9. Botet Del Castillo FX, Lopez S, Reyes G, et al. Diagnosis of retained abdominal gauze swabs. $\mathrm{Br} \mathrm{J}$ Surg 1995;82(2):227-8.

10. Gonzalez-Ojeda A, Rodriguez-Alcantar DA, ArenasMarquez $\mathrm{H}$, et al. Retained foreign bodies following intraabdominal surgery. Hepatogastroenterology 1999;46(26):808-12.
11. O'Connor A, Coakley F, Meng M, et al. Imaging of retained surgical sponges in the abdomen and pelvis. AJR 2003;180(2):481-9.

12. Adonis Manzella, Paulo Borba Filho, Eolo Albuquerque, et al. Imaging of gossypibomas: pictorial review. American journal of roentgenology 2009;193(6):94-101.

13. Childers JM, Caplinger P. Laparoscopic retrieval of a retained surgical sponge: a case report. Surg Laparosc Endosc 1993;3(2):135-8.

14. Kubota A, Haniuda N. A case of retained surgical sponge (gossypiboma) and MRI features. Jpn J Gastroenterol Surg 2000;33:1719-23. 